\title{
Housing policy in Mexico and its impacts
}

\author{
J. Audefroy \\ Escuela Superior de Ingeniería y Arquitectura (ESIA-Tecamachalco), \\ National Polytechnic Institute IPN, Mexico
}

\begin{abstract}
This paper attempts to demonstrate that while housing policy in Mexico is aimed at satisfying the needs of the construction sector and the demand for housing, it does not consider climatic effects, soil quality or consequences for the existing housing inventory. Therefore, the residential complexes built during the last 1520 years are exposed to a number of threats including flooding, subsidence and crack, as well as hurricanes in the case of housing built along coastlines. There is an inconsistency between housing policy and the housing demand for lowincome families, most of whom are unable to access public housing programs. The result is that, first of all, low-income families acquire land not suitable for construction, and are thus highly vulnerable to hydrometeorological and edaphological effects, and secondly, some housing developers acquire territorial reserves at a low cost, in order to increase their own benefits, but the land is not always suitable for housing construction. One case is presented in the current study in the Iztapalapa city district of Mexico City (Federal District), where residential complexes have been authorized without considering environmental impacts or existing hazards.
\end{abstract}

Keywords: housing policy, hazards, vulnerability, territorial reserves, Mexico.

\section{Introduction}

The guidelines for housing policy in Mexico have been established within the framework of plans and programs such as the 2007-2012 National Development Plan and the 2009-2012 National Urban Development Plan. One of the objectives defined by the latter is "to establish preventative actions and timely responses to natural hazards" and "to build dense, compact cities with a combination of compatible land uses." These objectives orient urban and housing policy. 
The public strategy for supporting the construction of new residential complexes is manifested through bridge credit lines and through the challenge of building residential complexes that incorporate sustainability characteristics on a massive scale. To this end the public sector has created a program known as Esta en tu casa (This is your home), and since March 1, 2009, it has incorporated the condition that new housing units have a basic package of measures for minimizing the use of water, electricity and gas, with the aim of mitigating the effects of climate change and its negative consequences for the environment.

The response since 2001 from construction companies such as GEO, ARA, HOMEX, URBI, SARE, and the HOGAR consortium has been significant. In the state of Mexico alone, we find that from 1999 to 2009, a total of 555,722 housing units have been built, benefitting 2.5 million families.

However, not all of the residential complexes have been constructed in safe zones, and the housing built in coastal areas is vulnerable to hurricanes. In addition many housing developments have been built on land where all types of fissures have occurred, in areas where the land is sinking, and in areas characterized by flooding. The entities that issue building permits do not necessarily review hazard maps, when such exist, and many municipalities do not yet have this type of map.

National housing policy is oriented toward producing housing that will mitigate the effects of climate change, but there are no specifications or particular standards in building regulations. No specific consideration is given to anthropogenic or natural hazards in the process of constructing new housing developments.

In addition housing policy neglects approximately $60 \%$ of the population that does not have access to public programs (INFONAVIT and FOVISSSTE, SHF and FONHAPO), plus "environmental deterioration displaces poor people who end up living in hazardous zones" (WSF [1]). This population in need of housing has no other option but to occupy (through purchasing or invading) land that is unsuitable for construction. Consequently, every year approximately 90,000 households settle in hazardous areas with precarious modalities and located far from workplaces.

\section{Housing policy in Mexico}

The production of housing and especially public housing has increased notably since 2001. From January 2001 to December 2005, 3,394,973 loans and subsidies were granted in different program modalities. Of this number, 2,321,331 were granted for the purpose of acquiring housing, and 1,073,642 for housing improvement and other types of loans (CIDOC [2]). In terms of the private sector, mortgage loans granted by SOFOLES increased from 45,556 to $102,377(+224 \%)$ from 2000 to 2005 , and to 110,995 in 2007, and then dropped to 99,487 in 2008. Development Banks went from granting almost no loans at all to 55,537 loans in $2005 ; 54,119$ in 2007 ; and 88,671 in 2008 . As for INFONAVIT and FOVISSSTE, the number of loans granted increased from 458,701 in 2007 to 494,073 in 2008 [2], and from 70,528 in 2007 to 90,140 in 
2008 , respectively. In other words, a significant increase in the number of loans granted by all public and private credit institutions can be observed over a period of eight to nine years.

The housing market in Mexico is of a significant size, but in constant fluctuation. Following a major decline in 2009, housing construction (of individual houses, housing complexes and departments) began to increase again, beginning in 2010. The annual percentages of the GDP corresponding to housing from 2006 to 2011 were as follows [2]:

Table 1: Housing GDP for 2006-2011, annual percentage variation (Source: CIDOC; 2011).

\begin{tabular}{|c|c|c|c|c|c|c|}
\hline Years & 2006 & 2007 & 2008 & 2009 & 2010 & 2011 \\
\hline $\begin{array}{c}\text { Annual \% } \\
\text { of GDP }\end{array}$ & 17.6 & 7.8 & 9.6 & -15.4 & -1.9 & 5.6 \\
\hline
\end{tabular}

There are approximately 4,370 housing construction and development companies in Mexico in 2011 [2]. Six of the eleven largest companies are listed on the Mexican Stock Exchange: GEO Corporation, ARA Consortium, HOMEX Developers, SARE Holding, URBI, and HOGAR Consortium. The volume handled by these six companies represents $1.4 \%$ of the GDP corresponding to housing construction for the second quarter of 2011. All of these are vertically integrated companies; they buy land, install services, build houses, and sell the houses with services, ready for applying for loans from credit entities. They have a long-term vision, with a policy of purchasing territorial reserves. Between 2005 and 2007, the value of GEO stocks increased from 27.35 to 64.25 (see Figure 1).

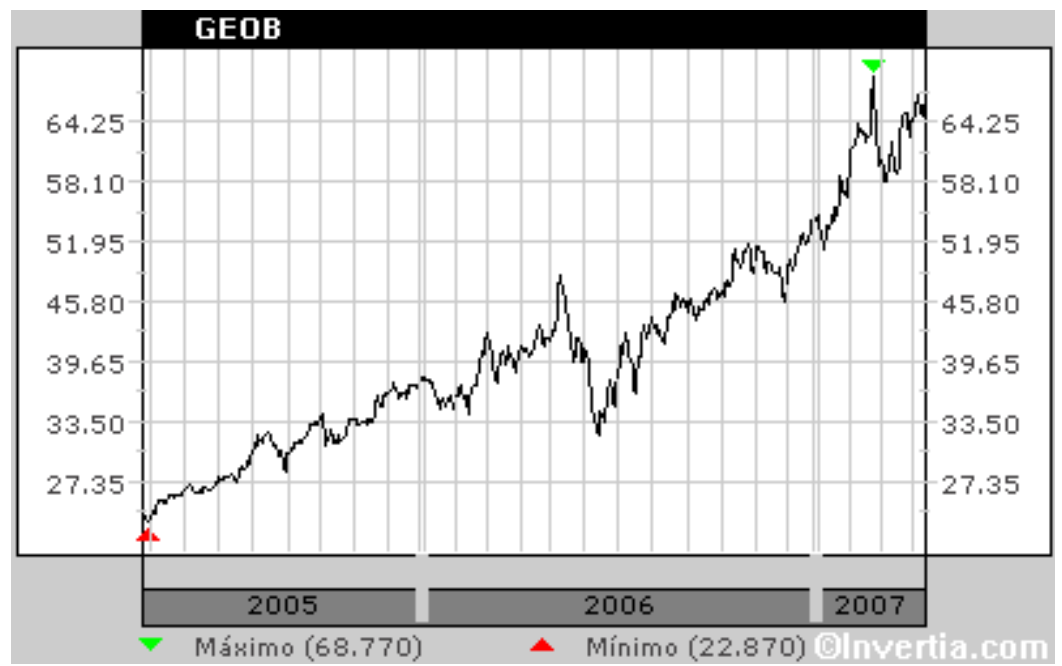

Figure 1: Value of GEO stock between 2005 and 2007 (source: GEO). 
In the second half of 2011, GEO was the company with the most housing units with deeds, at 14,724, followed by Homex with 12,576 housing units, and URBI, which obtained deeds for nearly 9,000 housing units. The company with the most territorial reserves is Homex, with 8,020 hectares, followed by GEO and URBI, as indicated in the following table:

Table 2: $\quad$ Housing units and territorial reserves (2011).

\begin{tabular}{|l|c|c|}
\hline \multicolumn{1}{|c|}{ Developer } & $\begin{array}{c}\text { Housing units with } \\
\text { deeds } \\
\text { (Number) }\end{array}$ & $\begin{array}{c}\text { Territorial reserves } \\
\text { (Hectares) }\end{array}$ \\
\hline Geo & 14,742 & 7,167 \\
\hline Homex & 12,576 & 8,020 \\
\hline Urbi & 8,932 & 5,690 \\
\hline Ara & 4,387 & 4,450 \\
\hline Sare & 837 & 862 \\
\hline Hogar & 477 & 726 \\
\hline Total & 41,951 & 26,915 \\
\hline
\end{tabular}

(Source: CIDOC, 2011, with information from SHF and the Mexican Stock Exchange).

CIDOC [2] estimates that six of the 18 worst public housing complexes evaluated were built by GEO, according to information from a survey on housing satisfaction conducted in all Mexican states. The results of the survey are based on a "satisfaction with housing" index, which is the average weighed from the scores given to physical characteristics associated with construction, space and functionality, plus adaptations, transformations and environmental characteristics. The only scores that dropped from 2009 and 2010 were associated with environmental characteristics. This means that public housing is poorly adapted or adaptable to climate and the environment.

According to the CIDOC study [2], the number of housing units will increase by a factor of 1.5 from 2010 to 2040 , from 28.6 million to 43.2 million, equivalent to 486,000 housing units every year. If we consider that 251 square meters of land are needed for each housing unit, there will be a demand for over 351,000 hectares of land suitable for construction. In reality this suitable land does not exist in cities or their peripheries. Government Housing Entities (Organismos Estatales de Vivienda - OREVIS) and developers alone have only $15 \%$ (52,650 hectares) of the total land needed, and it is supposedly suitable for building. Beginning in the $2040 \mathrm{~s}$, there will be excessive regularization of land to resolve the insufficient availability of land, and housing will be built on land vulnerable to flooding or exposed to threats such as land fissures and sinking, and hurricanes - even more than today. There will be a rise in the value of urban land suitable for construction (due to its limited availability), and developers will opt to use land unsuitable for building.

In the Strategic Guidelines for Housing in the 2007-2012 National Development Program, assistance for the segment of the population with housing needs is only planned in the case of natural disasters and in high-risk areas. A 
prevention-oriented phase of generating access for low-income families to land suitable for building is not considered.

There is currently intense pressure on land use from the increased housing demand caused by the growing young-adult population that has multiplied the number of households. According to the report entitled "Current housing situation in Mexico 2009," approximately 45,071 hectares of land will be needed by 2012 for the segments of the population earning less than three minimum wages. This represents $54.4 \%$ of total land requirements primarily in urban localities. And this means that 3.988 million dwellings will be needed over the next five years (see Figure 2).

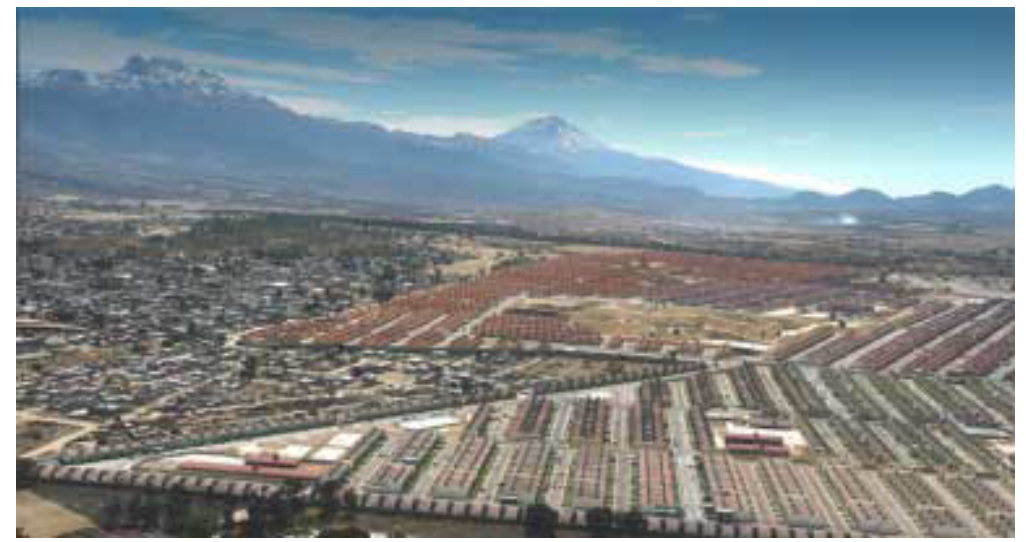

Figure 2: $\quad$ ARA Complex in Puebla (source: ARA).

Water-related conflicts in the state of Mexico demonstrate that urban planning has a determining role in social risk construction, with the latter understood as a process of decision-making based on knowledge derived from the connection between natural and social sciences. Deficiencies in this connection, the absence of its transformation into coherent territorial ordering and public policies, and inconsistency in its implementation are all determining factors in increased urban vulnerability, and thus, risks from natural and human-caused disasters. Housing policy in Mexico plays a part in this inconsistency, and thus contributes to social risk construction.

\section{Hydrometeorological hazards for the existing housing (formal and informal) inventory}

Socially produced housing, as well as dwellings financed by public housing entities, are more vulnerable to geological hazards (land fissures, land sinking), because they are built on land acquired at lower cost. They are also highly vulnerable to hydrometeorological phenomena such as hurricanes and flooding because they are not sufficiently adaptable to climate variability. Few processes of adaptation to climatic phenomena and threats have been integrated into social 
housing production thus far. Housing designs are very similar in all types of settings. The satisfaction survey cited earlier in this document indicates a deficiency in the designing of public housing with respect to environmental adaptation.

Vernacular dwellings in Mexico are more adaptable to these phenomena. For example, the Mayan dwellings used in the Yucatan have roofs adapted to the strong winds from hurricanes. Also, some Chontal homes in flood-prone areas of Tabasco are permanently built on piles. Another problem encountered is that hazard zoning maps - when they exist - are not always issued by those responsible for urbanization, and the latter tend to view them as more of an obstacle than an important tool.

According to Hernández Cerda et al. [3], the main areas considered to be the most vulnerable to hurricanes are the following:

- Peripheries of urban areas, since there are few buildings to reduce wind velocity. Generally, peripheral areas are those where precarious dwellings are found and are the first to suffer damages.

- Zones in which a localized increase in wind is expected due to topographic characteristics, such as areas located on rising slopes.

- Tall or high-altitude buildings may receive gusts of wind up to 250 kilometers per hour.

- Areas where strong wind currents develop, as in canyons and narrow streets.

- Areas with ocean exposure, such as tourist areas and hotels, are the most vulnerable. It is worth mentioning here that Mayan dwellings in the Mexican Caribbean region are not traditionally built in exposed areas along coastal areas.

Precipitation produced by hurricanes in the Caribbean region are sometimes extreme (accumulations above $400 \mathrm{~mm}$ in a single day) and produce flooding, especially when there are limited areas where seepage may occur. The main threat from intense rainfall in rural areas is the possibility of landslides and mudflows, as in the case of Hurricane Stan in 2005 in Chiapas, particularly in Motozintla. In addition, housing located along the Cancún coastline are particularly exposed to ocean swells, wind and flooding.

The Mexican Institute of Water Technology (Instituto Mexicano de Tecnología del Agua - IMTA), in its analysis entitled "Análisis de posibles impactos del cambio climático (Analysis of possible impacts of climate change) [4], recommends implementing regulations for appropriate construction in the Caribbean region near Cancún:

- Non-structural elements (finishing details) are very fragile when exposed to strong winds. The use of cortinas designed to provide protection from extreme winds is recommended.

- Hotels and buildings located near the Caribbean Sea should be designed or redesigned to consider the possibility of the combined effects of storm tides and surges from extreme hurricane conditions (with wave heights up to 14 meters). 
According to Magaña and Gay García [5], there are approximately 18 million inhabitants at this time living in areas at high risk of flooding. This means that one-fifth of the country's population has one of the highest degrees of vulnerability to climatic variations caused by El Niño/La Niña events or tendencies toward increased extreme hydrometeorological events caused by the earth's warming, such as more severe hurricanes, for example. The main causes of flooding are the overflowing of rivers, intense tropical rains and hurricanes accompanied by torrential rainfall. In Mexico, three states are particularly affected by intense rainfall. Specifically, Chiapas, Tabasco and Veracruz already receive between 1,500 and 2,500 $\mathrm{mm}$ of annual average precipitation, and these levels will increase further with climate changes. The case of Tabasco in October 2007 (with $80 \%$ of the state flooded) is a perfect example that illustrates the effects of socially and politically constructed vulnerability and points to the significance of climate change.

The main effects from flooding on habitats are generally irreversible in the case of precarious and traditional dwellings (made from wood, corrugated cardboard or materials such as adobe and bajareque). Adobe constructions cannot resist flooding for very long, because clay has a very high absorption coefficient and it turns into mud. Dwellings along riverbanks are the most seriously exposed (especially if located on a former riverbed). The risks increase with the growth of human settlements in flood-prone areas, and due to modifications in land surfaces, such as destruction of vegetation and soil erosion (Lugo Hubp and Inbar [6]). Cities and urban areas in general are prone to flooding because natural surfaces that allow for water seepage are very limited (only parks and gardens, etc.).

\section{The case of housing in Iztapalapa}

The case of the Iztapalapa district of Mexico City is interesting because it is the city district with the greatest population and the most hazards, including flooding, standing water, subsidence and crack Overpopulation in this city district has spread extensively throughout its territory, including areas characterized by more serious hazards, such as areas with uneven terrain and geological faults, making them unsuitable for urban development (PDDU [7]). The population is therefore highly vulnerable. Iztapalapa is perhaps the city district in which the most residential buildings have been established, and on extremely unstable soil. Building permits for residential complexes have been issued since the 1960s without requiring developers to conduct technical soil testing. Consequently, 716 residential complexes have been built, and are distributed throughout the district: 12 in Santa Catarina; 135 in Paraje San Juan; 47 in Ermita Zaragoza; 72 in Cabeza de Juárez; 83 in the Centro; 128 in Aculco; and 239 in San Lorenzo. The 2005 Census calculated a population of 1,820,888 inhabitants residing in 441,334 housing units in this city district. According to INEGI, most of the housing in this district consists of vivienda en conjunto (housing complexes) and casa independiente (single houses) (69.48\% and 
$18.48 \%$, respectively), with the rest distributed among what may be considered to be inadequate types of housing.

The problem of housing with the potential for hazards is found in neighborhoods located in mined areas, with geological faults running through, or on unstable soil of lacustrian origin. In neighborhoods such as Santa Cruz Meyehualco, Ejército de Oriente zona Peñón, José María Morelos y Pavón, Vicente Guerrero, and Ermita Zaragoza, the main hazards are derived from geological elements, from the readjusting of tectonic layers or fissures in the subsoil (PPDU [7]). It is estimated that 50\% of the land surface in the city district is located in a lacustrian zone (Lagos de Chalco-Xochimilco and Texcoco). This means the land is of poor quality for constructing buildings, and thus housing built by owners may be at risk (PDPC [8]). This also signifies that a large number of residential complexes that complied with the provisions in building regulations at the time of construction do not comply with current provisions with respect to the resistance and deformability that must be maintained in order to tolerate the effects from high-magnitude earthquakes.

Approximately $40 \%$ of the territory in the Iztapalapa district is affected by problems associated with the risk of land fissures, subsidence or giving way, mining cavities and unstable slopes, affecting 1,746 constructions, primarily residential buildings, and representing an element to be considered in future constructions. Due to differential sinking in the district's territory and deficiencies in the sewage systems, areas at risk due to flooding and standing water have been detected, affecting the population's health, assets and traffic (Atlas de riesgo, Delegación Iztapalapa [9]).

In 2005 a total of 1,746 housing units with detectable cracks in seven neighborhoods were identified. Most of the housing units affected are in residential complexes, as mentioned in Table 5. In 2012 property taxes were cancelled in 22 neighborhoods and residential complexes in Iztapalapa due to structural damage. Specifically: "The Mexico City government will cancel property taxes for those owning or possessing property with structural damages caused by land fissures or sinking" (El Universal, October 2012).

The problem is so severe that not a great deal can be done technically except to demolish the damaged homes or buildings. In some cases buildings have been temporarily vacated, as in the case of Unidad Habitacional Juárez 34. Specifically, after structural damage was verified in buildings " $\mathrm{H}$ " and " $\mathrm{J}$ " in a technical report prepared by the Center for Monitoring Fissures in Subsoil, Iztapalapa's Civil Protection Unit initiated efforts to evacuate the buildings, each of which contained 20 apartments. With assistance from the Iztapalapa local government, inhabitants began to evacuate their apartments. Each apartment owner received an economic subsidy of approximately 3,000 pesos a month from the Natural Disaster Fund (Fondo de Desastres Naturales - FONDEN), in exchange for leaving the building and renting other housing during the process of leveling the buildings. For a period of six months, apartment owners received this economic assistance on a regular basis. After that, delays in the bank deposits began, and then the necessary budget for granting this subsidy was no longer available. Consequently, some inhabitants decided to return to their 
apartments (12 apartments in all) and reside there once again, despite the recommendations made by the Center for Monitoring Fissures in Subsoil (Sánchez Chávez [10]).

The housing situation in Iztapalapa is, to some degree, the consequence of a housing policy that has permitted the construction of residential complexes since the 1960s (by INDECO) without the necessary soil analysis. Furthermore, due to the ongoing extraction of underground water, the problem has intensified and caused more sinking of land and more fissures, and thus more damage to buildings.

\section{Discussion and conclusions}

Although elements of climate change have been taken into consideration in housing policy since 2009, through the program known as Esta es tu casa, with a basic package of measures for minimizing use of water, electricity and gas, there is inconsistency between urban planning (urban development plans) and housing policy, which is designed for major construction companies, to enable them to make huge profits with support from public housing programs (INFONAVIT, FOVISSSTE, etc.). Government financial assistance, with the goal of reaching $40 \%$ of the population, was achieved as a result of the Program for Financing Schemes and Federal Subsidies for Housing (Programa de Esquemas de Financiamiento y Subsidio Federal para Vivienda) (2007). The objective was to facilitate housing for families earning four minimum wages (6,000 Mexican pesos a month) or less, representing $40 \%$ of the population.

The real estate business operates in such a way that in its initial stage, large land plots are purchased without utilities and located on the periphery of cities, without any real concern for the possibility of natural threats or hazards. Then, the land is urbanized and numerous residential complexes are established, typically with a model for a standard of living in accordance with low and middle-income housing. In terms of land use, the major developers involved have a long-term vision with a business perspective, and have specialized departments for acquiring and administering land, consistently looking for profitable purchase opportunities.

Both the disappearance of direct subsidies for acquiring land and housing, and reforms made to the public entities responsible for low-cost housing (basically FONHAPO and INFONAVIT) - with the objective of enhancing their financial and operational efficiency - have led to restrictions on access to financing for acquiring housing, affecting workers with minimum income levels and those who are underemployed, and have led to practically the complete disappearance of public assistance for acquiring low-cost housing and for helping individuals build their own housing.

For nearly a decade now, the incorporation of land in urban development - in the terms anticipated by urban development plans in population centers and particularly dedicated to low-cost housing - has been regulated almost exclusively by criteria dictated by the real estate market. For the population with the greatest housing needs, the fewest economic resources, and the aspiration to 
obtain financing for their housing, this has signified being abandoned outside the market's formal channels.

Given the minimal participation by programs for progressive housing and improvement, and considering that nearly two-thirds of the housing inventory in Mexico and over half of new housing constructed corresponds to housing built by the individuals who own it, it is clear that a significant sector of the population is not receiving the attention it requires through the current financing schemes. If we also consider the fact that $75 \%$ of the housing in the entire country is in need of some level of repair, including 14\% that most likely needs to be completely replaced, the problem is indeed serious and we may conclude that existing housing is characterized by a high level of vulnerability to hydrometeorological and edaphological phenomena.

By orienting housing policy to a limited sector of the population (new housing for middle-class families), for the benefit of major developers, the housing units requiring improvements or replacement have been neglected during the last two six-year presidential terms, and therefore $75 \%$ of housing in Mexico is vulnerable to hydrometeorological events and earthquakes.

The goal of this paper has been to demonstrate the way in which risks may be socially constructed through policies. The case of housing policy and hydrometeorological and edaphological risks (in the case of Iztapalapa) has been presented here. However, the same exercise could be conducted with other policies, such as hazard management policy, which is focused more on emergency situations than on prevention, and in this way contributes to social risk construction.

\section{Acknowledgements}

The author expresses his appreciation to the institution that made this research possible: the SIP at IPN (SIP No. 20121231).

\section{References}

[1] FSM (WSF), Call from Rio de Janeiro "Hacia la asamblea mundial de los habitantes (Toward the World Assembly of Inhabitants).” 2010.

[2] CIDOC, SHF, CONAVI, Estado actual de la vivienda en México, Mexico, 2006.

- Estado actual de la vivienda en México 2009, Mexico, 2009.

- Estado actual de la vivienda en México, 2011, Mexico, 2011.

[3] Hernández Cerda, M. et al., Los ciclones tropicales de México, Instituto de Geografía, UNAM, Mexico, 2001.

[4] Prieto González, R.; Pérez López, J. L.; Sánchez Sesma, J., Análisis de posibles impactos del cambio climático, Estudio de caso preliminar, Cancún, Quintana Roo, IMTA, Mexico, 2006.

[5] Magaña,V.; Gay García, C., Vulnerabilidad y Adaptación Regional ante el Cambio Climático y sus Impactos Ambiental, Social y Económicos, INEUNAM, Mexico, 2000. 
[6] Lugo Hubp, J.; Inbar, M., Desastres naturales en América Latina, FCE, Mexico, 2002.

[7] Delegación Iztapalapa, Programa Delegacional de Desarrollo Urbano para la Delegación Iztapalapa (PDDU), Mexico, 2005.

[8] Delegación Iztapalapa, Programa Delegacional de Protección Civil (PDPC) 2009-2012, Mexico, 2009.

[9] Terracon Ingeniería, Atlas de riesgos naturales de la Delegación Iztapalapa, Mexico, 2011.

[10] Sánchez Chávez, J. A., La vivienda en Iztapalapa, riesgo por hundimiento y vulnerabilidad, Master's thesis, ESIA-Tecamachalco, IPN, Mexico, 2012. 